\title{
Group B streptococci in venereal disease clinic patients
}

\author{
JOHAN WALLIN AND ARNE FORSGREN \\ From the Department of Dermatology and Venereology, University Hospital, Uppsala, and the Institute of \\ Clinical Bacteriology, University of Uppsala, Sweden
}

The frequency of neonatal infections caused by vaginal group B streptococci seems to increase (Baker and Barret, 1973; Franciosi, Knostman, and Zimmerman, 1973; Bergquist, Hurvell, Malmborg, Rylander, and Tunell, 1971a; Bergquist, Hurvell, Thal, and Vaclavinkova, 1971b). In 45 per cent. of the male partners of women with a vaginal growth of group B streptococci, Franciosi and others (1973) were able to demonstrate a urethral growth of streptococci with the same group B serotype. The bacteria are thus potentially pathogenic and probably sexually transmitted. The main purpose of the following study was to evaluate the importance of this organism for the development of genital disease.

\section{Material and methods}

All patients attending the Venereal Diseases Clinic of the University Hospital in Uppsala between September and November, 1974, were included in the study, with the exception of those who had taken any type of antibiotic within a 2-week period before their visit. The final series comprised 457 men and 300 women ranging in age from 14 to 63 years, 78 per cent. being between 18 and 29 years. A careful history was taken from each patient.

\section{CLINICAL PROCEDURE}

The majority of patients telephoned for their appointments with the clinic and were then told to retain their urine for at least $3 \mathrm{hrs}$ before the examination. Specimens for culturing Neisseria gonorrhoeae and group B streptococci were taken with charcoal-coated cotton-wool swabs from the urethra in men and from the urethra, cervix, and rectum (gonococci only) in women and transported in Stuart's medium.

Smears were made from the discharge that was obtained by scraping the urethral mucosa of the men and the cervical mucosa of the women. After staining with methylene blue, a direct microscopical examination was made for gonococci and polymorphonuclear leucocytes. Ten or more white blood cells per high-power field seen

Received for publication April 20, 1974

Address for reprints: Dr. J. Wallin, M.D., Dept. of Dermatology, University Hospital, S 75014 Uppsala, Sweden in several fields with an $\times 100$ objective and $\times 12.5$ oculars were recorded as a leucocytic reaction.

\section{MICROBIOLOGICAL PROCEDURE}

On arrival at the laboratory, material from the swabs was inoculated onto conventional media for the isolation of $N$. gonorrhoeae as described earlier (Gnarpe, Wallin, and Forsgren, 1972). The final identification was made by an immunofluorescence technique (Forsum, 1972).

For isolation of group B streptococci the swabs were streaked on to gentian violet agar medium with 5 per cent. sheep blood. The cotton-wool swab cultures were also inoculated into tubes containing a selective broth medium for isolation of group B streptococci (Baker, Clark, and Barret, 1973) and the tubes were incubated for $18 \mathrm{hrs}$ at $37^{\circ} \mathrm{C}$. The broth cultures were then streaked on to gentian violet blood agar medium and developing colonies of betahaemolytic streptococci were subgrouped by the capillary precipitin method (Lancefield, 1933). The antigen extracts were prepared by the formamide method (Fuller, 1938) and group specific antisera (Wellcome) were used.

TABLE I Percentage of 457 men and 300 women with positive culture of $\mathrm{N}$. gonorrhoeae and Group $B$ streptococci

\begin{tabular}{llll}
\hline Sex & N. gonorrhoeae & & Group B streptococci \\
Male & $17 \cdot 7$ & $16 \cdot 4$ \\
Female & $21 \cdot 3$ & $20 \cdot 0$ \\
\hline
\end{tabular}

\section{Results}

As shown in Table $I$, approximately the same frequencies of $N$. gonorrhoeae and group B streptococci were found in this group of patients. The percentages of group B streptococci isolated represent results obtained with the use of a selective broth medium. The improvement of the bacteriological procedure through the use of the selective medium ranged from 30 to 40 per cent. (Table II). Positive cultures of group B streptococci from the women were obtained in 93 per cent. from the urethral specimens and in 67 per cent. from the cervical specimens. 
TABLE II Percentage positive cultures of Group B streptococci isolated from 457 men and 300 women with and without the use of a selective broth medium

\begin{tabular}{|c|c|c|}
\hline Medium & Men & Women \\
\hline Gentian violet blood agar & $11 \cdot 6$ & $15 \cdot 4$ \\
\hline $\begin{array}{l}\text { Selective broth medium }+ \\
\text { Gentian violet blood agar }\end{array}$ & $16 \cdot 4$ & $20 \cdot 0$ \\
\hline
\end{tabular}

RELATION TO GONOCOCCAL INFECTION AND PROMISCUITY

Group B streptococci were isolated from $11 \cdot 1$ per cent. of the men with gonorrhoea and from 17.6 per cent. of the men without gonorrhoea. This difference is not statistically significant. The corresponding figures for the women are 21.9 and 19.5 (Table III).

TABLE III Percentage Group B streptococci isolated from 457 men and 300 women with and without a positive culture of $\mathrm{N}$. gonorrhoeae

\begin{tabular}{|c|c|c|c|}
\hline $\operatorname{Sex}$ & Gonorrhoea & No. of patients & $\begin{array}{l}\text { Group B } \\
\text { streptococci } \\
\text { (per cent.) }\end{array}$ \\
\hline Male & $\begin{array}{l}\text { Present } \\
\text { Absent }\end{array}$ & $\begin{array}{r}81 \\
376\end{array}$ & $\begin{array}{l}11 \cdot 1 \\
17 \cdot 0\end{array}$ \\
\hline Female & $\begin{array}{l}\text { Present } \\
\text { Absent }\end{array}$ & $\begin{array}{r}64 \\
236\end{array}$ & $\begin{array}{l}21.9 \\
19.5\end{array}$ \\
\hline
\end{tabular}

In order to study the importance of promiscuity for the spread of group B streptococci, the patients were grouped according to a promiscuity factor, i.e. number of partners during a period of 1 month before the examination. Table IV shows that, of the men with more than one partner, gonorrhoea was found in 25.2 per cent. compared with 14.6 per cent. in those with one partner or none $(P<0.01)$. The corresponding figures for the women (Table IV) were 29.7 and 18.6 per cent. respectively $(P<0.05)$. The isolation rates for group B streptococci were not significantly increased in those with several partners.

TABLE IV Percentage N. gonorrhoeae and Group $B$ streptococci isolated from 457 men and 300 women grouped according to number of sexual partners in preceding 30 days

\begin{tabular}{|c|c|c|c|c|}
\hline Sex & $\begin{array}{l}\text { No. of } \\
\text { partners }\end{array}$ & $\begin{array}{l}\text { No. of } \\
\text { patients }\end{array}$ & $\begin{array}{l}\text { N. } \\
\text { gonorrhoeae }\end{array}$ & $\begin{array}{l}\text { Group B } \\
\text { streptococci }\end{array}$ \\
\hline Male & $\begin{array}{l}\leqq 1 \\
>1\end{array}$ & $\begin{array}{l}322 \\
135\end{array}$ & $\begin{array}{l}14 \cdot 6 \\
25 \cdot 2^{2}\end{array}$ & $\begin{array}{l}16 \cdot 2 \\
17 \cdot 0\end{array}$ \\
\hline Female & $\begin{array}{l}\leqq 1 \\
>1\end{array}$ & $\begin{array}{r}226 \\
74\end{array}$ & $\begin{array}{l}18 \cdot 6 \\
29 \cdot 7^{b}\end{array}$ & $\begin{array}{l}18 \cdot 6 \\
24 \cdot 3\end{array}$ \\
\hline
\end{tabular}

${ }^{\mathrm{a}} \chi_{1}^{2}=6.96 ; P<0.01$

${ }^{b} \chi_{1}^{2}=4.04 ; P<0.05$

$\mathbf{P}=$ The probability that the difference between the group with more than one partner and the other group is cau sed by random factors.

\section{SYMPTOMS OF GENITAL INFECTION}

Because a gonococcal infection may cause symptoms of genital disease, patients with a positive culture of
$N$. gonorrhoeae were excluded from this part of the study. As demonstrated in Table V, the presence of symptoms such as urethral discharge or dysuria in men could not be related to a positive isolation of group B streptococci. Neither could the positive specimens of group B streptococci from women without gonorrhoea be related to vaginal discharge or dysuria (Table V).

TABLE V Percentage Group B streptococci isolated from 376 men and 236 women without gonorrhoea, with and without discharge or dysuria

\begin{tabular}{|c|c|c|c|}
\hline Sex & Signs & No. of patients & $\begin{array}{l}\text { Group B } \\
\text { streptococci }\end{array}$ \\
\hline \multirow[t]{2}{*}{ Male } & $\begin{array}{l}\text { Discharge } \\
\text { No discharge }\end{array}$ & $\begin{array}{l}145 \\
231\end{array}$ & $\begin{array}{l}13 \cdot 1 \\
20 \cdot 4\end{array}$ \\
\hline & $\begin{array}{l}\text { Dysuria } \\
\text { No dysuria }\end{array}$ & $\begin{array}{l}171 \\
205\end{array}$ & $\begin{array}{l}15 \cdot 2 \\
19 \cdot 5\end{array}$ \\
\hline \multirow[t]{2}{*}{ Female } & $\begin{array}{l}\text { Discharge } \\
\text { No discharge }\end{array}$ & $\begin{array}{l}131 \\
105\end{array}$ & $\begin{array}{l}19 \cdot 9 \\
19 \cdot 1\end{array}$ \\
\hline & $\begin{array}{l}\text { Dysuria } \\
\text { No dysuria }\end{array}$ & $\begin{array}{r}76 \\
160\end{array}$ & $\begin{array}{l}17 \cdot 1 \\
20 \cdot 6\end{array}$ \\
\hline
\end{tabular}

SIGNS OF GENITAL INFECTION

Table VI shows the incidence of leucocytic reaction in the urethra of 376 men and in the cervical mucosa of 236 women. Group B streptococci could not be related to a leucocytic reaction in the male urethral smears but group B streptococci were isolated from women with no leucocytic reaction in 23.1 per cent. as compared with 10.5 per cent. from women with this reaction $(P<0.05)$.

TABLE VI Percentage Group B streptococci from men and women without gonorrhoea, with and without leucocytic reaction in urethra and cervix respectively

\begin{tabular}{|c|c|c|c|}
\hline Sex & $\begin{array}{l}\text { Leucocytic } \\
\text { reaction }\end{array}$ & No. of patients & $\begin{array}{l}\text { Group B } \\
\text { streptococci }\end{array}$ \\
\hline $\begin{array}{l}\text { Male } \\
\text { (urethra) }\end{array}$ & $\begin{array}{l}\text { Present } \\
\text { Absent }\end{array}$ & $\begin{array}{l}154 \\
222\end{array}$ & $\begin{array}{l}17 \cdot 5 \\
17 \cdot 6\end{array}$ \\
\hline $\begin{array}{l}\text { Female } \\
\text { (cervix) }\end{array}$ & $\begin{array}{l}\text { Present } \\
\text { Absent }\end{array}$ & $\begin{array}{r}67 \\
169\end{array}$ & $\begin{array}{l}10 \cdot 5 \\
23 \cdot 1 \mathrm{a}\end{array}$ \\
\hline
\end{tabular}

${ }^{2} \chi_{1}^{2}=5.12 ; P<0.05$

$\mathbf{P}=$ The probability that the difference between the group of women with a leucocytic reaction and the group without is caused by random factors

Group B streptococci were found significantly more often in men with condylomata acuminata than in men without (Table VII) $(P<0.001)$. A similar study was undertaken for women, but there were too few cases of condylomata acuminata in women during the period of the study for conclusions to be drawn. 
TABLE VII Percentage Group B streptococci from 236 men without gonorrhoea with and without condylomata acuminata

\begin{tabular}{|c|c|c|}
\hline $\begin{array}{l}\text { Condylomata } \\
\text { acuminata }\end{array}$ & No. of patients & Group B streptococci \\
\hline $\begin{array}{l}\text { Present } \\
\text { Absent }\end{array}$ & $\begin{array}{l}48 \\
409\end{array}$ & $\begin{array}{l}33 \cdot 3^{n} \\
14 \cdot 4^{n}\end{array}$ \\
\hline
\end{tabular}

\section{Discussion}

For many decades group B streptococci have been considered to be saprophytic in man (Ayers and Rupp, 1922), but Fry (1938) pointed out their pathogenicity and described three cases of fatal puerperal infection caused by these bacteria. Since then, group B streptococci have been shown to cause different types of infection in adults and neonates (Butter and Moor, 1967; Eickhoff, Klein, Daly, Ingal, and Finland, 1964; Hood, Janney, and Dameron, 1961; Müller, 1967; Toft and Jespersen, 1968; Bergquist and others, 1971a; b).

According to Eickhoff and others (1964), 'the reservoir of this organism in the human population is not known, but the adult female genital tract is certainly a major one'. Lancefield and Hare (1935) found 3 per cent. of clinically uninfected women to have group B streptococci during the puerperium. Hood and others (1961) reported that 5.8 per cent. of women at term harboured group B streptococci in the cervix. Bergquist and others (1971a) found group B streptococci in the urethra or cervix of seventeen of 118 pregnant women examined at term.

The high frequency of group B streptococci isolated from the women included in our study compared with the frequencies reported in some earlier studies is at least partly caused by the use of a selective broth medium. The isolation rate increased 30 per cent. for women and 40 per cent. for men through the use of a selective medium containing nalidixic acid and gentamycin sulphate. Using this type of medium, Baker and Barret (1973) isolated group B streptococci from 25.4 per cent. among parturient women. Furthermore, we found that, by taking specimens from the urethra in addition to the cervix, the frequency of isolation increased more than 30 per cent. for women. In fact, no less than 93 per cent. of all positive cultures were obtained from the urethral specimens.

Christensen, Christensen, Flamholc, and Ripa (1974) reported a connection between $N$. gonorrhoeae and group B streptococci, but in the present study neither the harbouring of gonococci nor a promiscuity factor was related to positive cultures of group B streptococci. The promiscuity factor has earlier been demonstrated to influence the spread of gonorrhoea
(Juhlin, 1968; Wallin, 1974) and the expected positive correlation between gonorrhoea and the number of partners was also found in this study.

No such correlation was found between the presence of polymorphonuclear leucocytes in smears from the male urethra and the growth of group B streptococci as is reported for the gonococci (Wallin, 1975). In women, however, the presence of leucocytes in cervical smears was found to be concomitant with a probable lower frequency of isolated group B streptococci. The explanation of this negative correlation is not clear but could be an expression of local phagocytosis or of a bactericidal effect of the polymorphonuclear leucocytes.

In men with condylomata acuminata there was a high incidence of group B streptococci; one reasonable explanation for this could be a generally decreased mucosal resistance to micro-organisms including group B streptococci.

Our results indicate that group B streptococci are unimportant for the presence of symptoms of genital infection such as dysuria and urethral or vaginal discharge. This absence of clinical signs and symptoms of infection in association with colonization by group B streptococci indicates that there is no general need for antibiotic treatment in patients with positive cultures of these streptococci. In the pregnant women, however, different types of organisms mean a potential risk for puerperal and neonatal infections (Nahmias, Alford, and Korones, 1970; Jones, Collier, and Smith, 1959; Platt, 1971) and this also applies to group B streptococci, especially in cases of obstetrical complication (Bergquist and others, 1971a) and prematurity (Franciosi and others, 1973).

The latter recommended that all pregnant women with a vaginal growth of group B streptococci should be given benzathine penicillin $G$, but this was challenged by Eickhoff, Klein, Mortimer, and Wherle (1973).

All pregnant women should have a urethral specimen taken for the culture of group B streptococci and the results should be recorded and made available during the pregnancy. If indications for treatment should appear before delivery this treatment should also include the male partner as this study showed a high frequency of male carriers.

\section{Summary}

The isolation rates of group B streptococci for 457 men and 300 women attending a venereal disease clinic were 16.4 and 20.6 per cent. respectively. The frequencies were significantly increased by using a selective medium and by taking specimens from the female urethra as well as the cervix. In contrast to gonorrhoea the presence of group B streptococci could not be related to promiscuity. In addition, the isolation of group B streptococci was found to be 
independent of a concomitant gonococcal infection. This study indicates that group B streptococci have little relation to the clinical signs and symptoms of genital infection, such as dysuria, discharge, and inflammatory mucosal reaction.

\section{References}

AYERs, S. H., and Rupp, P. (1922) F. infect. Dis., 30, 388 BAKER, C. J., and BARRET, F. F. (1973) f. Pediat., 83, 919

-, Clark, D. J., and Barret, F. F. (1973) Appl. Microbiol., 26, 884

BERGQUist, G., HURVELl, B., MALMBorg, A-S., RYLANDER, M., and Tunell, R. (1971a) Scand. F. infect. Dis., 3, 157

- Thal, E., and Vaclavinkova, V. (1971b) Ibid., 3, 209

Butter, N. N. W., and Moor, C. E. (1967) Antonie v. Leeuwenhoek, 33, 439

Christensen, K. K., Christensen, P., Flamholc, L., and RIPA, T. (1974) Acta path. microbiol. scand., Sect. B, 82, p.470

Eickhoff, T. C., Klein, J. O., Daly, A. K., Ingal, D., and Finland, M. (1964) New Engl. f. Med., 271, 1221
F. Pediat., 83, 1098

FORSUM, U. (1972) f. immunol. Meth., 2, 183

Franciosi, R. A., Knostman, J. D., and Zimmerman, R. A. (1973) f. Pediat., 82, 707

FRY, R. M. (1938) Lancet., 1, 199

Fuller, A. T. (1938) Brit. F. exp. Path., 19, 130

GNarpe, H., Wallin, J., and Forsgren, A. (1972) Brit. f. vener. Dis., 48, 496

Hood, M., JanNey, A., and Dameron, G. (1961) Amer. f. Obstet. Gynec., 82, 809

JONES, B. R., CollieR, L. H., and SMITH, C. H. (1959) Lancet, 1, 902

Juhlin, L. (1968) Acta derm.-venereol. (Stockh.), 48, 82

LANCEFIELD, R. C. (1933) F. exp. Med., 57, 571

and HARE, R. (1935) Ibid., 61, 335

MÜLLER, G. (1967) Arch. exp. Vet.-Med., 21, 43

Nahmias, A. J., AlFord, C. A., and Korones, S. B. (1970) Advanc. Pediat., 17, 185

Platt, M. S. (1971) Clin. Pediat., 10, 513

Toft, H., and Jesperson, C. S. (1968) Nord. Med., 80, 1401

WalliN, J. (1974) Thesis, Acta Univ. Upsaliensis, vol. 212, p.12

(1975) Brit. f. vener. Dis., 51, 41 